\title{
Legal Consequences of the Construction of a W all in the Occupied Sahrawi Territory
}

\author{
Juan SOROETALICERAS
}

\begin{abstract}
16stracl: During the armed conflict waged from 1975 to 199 between the Sahrawi and Moroccan armies, the occupy ing state built a wall that continues to be reinforced and has div ided in wo the territory of W estern Sahara. This article analy ses the legal consequences of the existence of the wall, and in particular of the fact that the POLIS IRIO Front still controls one third of the territory to the east of the wall, where the SIDR exercises the powers that correspond to a state.
\end{abstract}

Keywords: Wall, Self-Determination, Western Sahara, Law of Occupation, "Liberated territories"

\section{(}

The title of this article, which paraphrases that of the case in which the IC.J issued an advisory opinion in 200/in relation to Israel's construction of the wall in the occupied Palestinian territories', arises from certain premises upon which, despite being a part of the hard core of general international law, it is necessary to insist once again, as not only the European institutions themselves, but also some states have questioned or even denied, for example, the fact that the POLISARIO Front is a national liberation movement, that Spain is the administering power (this has been confirmed on three occasions by the Spanish National Iligh Court)or that Moroceo is the occupying power of the Sahrawi territory.

In October 1975 Morocco began the invasion of the "Spanish Sahara", by means of the so-called Green March, a supposedly peaceful invasion with which, in the words of King Ilassan II, the Moroccan people was going to "embrace their Southern brothers" (the "bear hug"?). Though officially the march was peaceful, the reality was very different. On the one hand, immediately behind this photogenic civilian procession draped in Moroccan flags, marched the powerful Moroccan army; on the other, this very same army had begun the invasion of the territory at other points on the Sahrawi-Moroccan border days prior to the start of the march. Following several years of combat, from 1980 onwards, with the help of Israel, the US I, France, Saudi Arabia and other states, Moroceo built five successive walls, stretching for almost 2,800 kilometres, which divided the Sahrawi territory in two.

This wall was intended to deny the POLIS XRIO Front access to the sea, where it continued its armed struggle, and distance it from the so-called "useful triangle", which included the phosphate deposits of Bu

¿ Irlicle published on ${ }_{31}$ December 2019

Lecturer in Public International Law. University of the Basque Country Euskal Iterriko Unibertstatea. This paper has been elaborated within the project DER2015-65986-R (financedby the Vinistry of Economy and Competitiveness) "Los muros en el Derecho Internacional Contemporáneo: Consecuencias para la Seguridad, la Dignidad I Iumana y la Sostenibilidad".

Legal Consequences of the Construction of a II all in the Occupied Palestinian Terrilory, Advisory Opinion, IC.J Reports 2004. 
Craaand the two main Sahrawi cities, El Aaiún and Smara. With the construction of the wall, the outcome of the war was decided; the Sahrawi army's military activity was gradually restricted toa zone within a few hundred metres of the length of the wall. It was clear that the POLIS ARIO Front, heavily outnumbered and outgunned by the Morocean army, could never defeat the latter.

However, in 1988 the enormous cost to Moroceo of maintaining along these 2,80o kilometres hundreds of thousands of soldiers and military hardware the condition of which deteriorated rapidly in such a harsh desert climate, forced King Ilassan II to sit down with the POLIS IRIO Front, which he had always branded as no more than a terrorist movement, and negotiate the Settlement Plan, which three years later was replaced by the so-called Peace Plan, which was finally approved by the U I Security Council. For, though as been noted, the Saharawi army could never hope to defeat its enemy in traditional warfare, it had the capacity to wage for many years the guerrilla war that it was engaging in within the vicinity of the wall. Of nomadic tradition and with expert knowledge of the land, el POLIS ARIO Front could launch simultaneous attacks at different points of the wall and flee at great speed, before the Moroccan army had time to respond, before attacking again at another point. ${ }^{2}$

These were the reasons why Moroceo recognised the need for a definitive solution to the conflict and negotiated with the POLIS IRIO Front, under the auspices of the United Vations and the Organisation for African Unity, the holding of a referendum on self-determination, with a fixed census and two possible options: integration within Moroceo or the territory's independence. This is not the place to recall the lengthy process of identification of voters or the obstacles sy stematically placed by Morocco to prevent the referendum, a question that I have analy sed in earlier works. Suffice it to say that the peace process was paraly sed when almost a decade later the beginning of the voter identification process (the Peace Plan anticipated the holding of referendum within six months!), in February 2000 the MINU RSO published the census for the referendum,i and Moroceo, after accusing the United Vations of favouring Saharawi interests, officially announced that it would never accept a referendum on self-determination in the territory. Although the Moroceo or French representatives frequently issue declarations to the effect that the referendum has not been held because "there are technical problems regarding the census over which agreement has not been reached", it should be made clear that these problems do not exist.

After a decade of hard work, and despite the repeated obstacles placed by Moroceo, the referendum census was correctly prepared by the MIXURSO. The only reason why the referendum has not been held is Morocco's refusal to fulfil its own commitments, a refusal unconditionally supported by France's veto in the Security Council, which in turn is openly applauded by the Spanish Government ${ }^{5}$. All that is required

\footnotetext{
2 Cf. I. Fuente Cobo and F. Mariño Méndez, El Confliclo del Sahara Occidental, Conflictos Internacionales Contemporáneos (nº, Ministry of Defence, Madrid, 2005) at 19-117.

3 Cf. my works 'El plan de Paz del Sahara Occidental, iviaje a ninguna parte?', so Revisla Electrónica de Esludios Inlernacionales (December 2005), at I-33; 'Vigencia del Plan de Paz del Sahara Occidental (ı991-2013)', in El derecho a la libre delerminación del pueblo del Sahara Occidenlal. Del ius cogens al ius abulendi (Thompson Reulers Aranzadi, Pamplona, 2013) at 199-226; 'The Conflict in Western Sahara After Forty Years of Occupation: International Law versus Realpolitik;, German Jearbook of Inlernational Law (59-2016) at 199-205.

4 Report of the Secretary General on the Situation concerning Western Sahara. U X Doc.S/2000/131 (2000), par. 6.

s Cf. J. González Vega, 'La España impasible: una aproximación crílica a nuestra política exlerior en relación con el
} 
in order to end the conflict is for the Security Council, acting within the framework of Chapter VII of the U I Charter, to decide to impose the application of the Peace Plan, which, moreover, was freely negotiated by both parties, deciding on the holding of the referendum, with the participation of those people included in the MINURSO census, in other words, the Saharawi people, and no-one else. But this unlikely to occur because France, which in other conflicts seeks to give human rights lessons to other States, vetoes any solution that is not acceptable to Moroceo. Let there be any doubt in this respect, it is worth recalling that France has on various occasions vetoed the US proposal that the MINURSO should have competences in questions of human rights.

Almost thirty years after the implementation of the ceasefire, the wall splits the Saharawi population in three: those who since 1975 have suffered the Moroccan occupation of their own land, those who had to flee the Morocean and escape to the Tinduf refugee camps, in the south of Ageria, and those who remain in the part of the territory that was never occupied by Moroceo, and which, therefore, is under the control of its actual owner, the Sahrawi people. The Moroccan wall also fulfils another of the original objectives at the time of its construction: leave the exploitation of the territory's natural resources, particularly phosphates and fishing, under the exclusive control of the occupving State.

\section{(B) TIIEOCCUPIEI TERRITORIES}

Is a starting point, it should be stated very clearly that the territories situated on the western side of the W all that limits the non-autonomous territory of the W estern Sahara are mililarily occupied lerrilories.

The International Court of Justice itself clearly established in its 1975 ruling on the Western Sahara some points that are worthwhile remembering. To this end I shall follow the order of the questions presented to the Court:

(1) About the time of the Spanish colonisation, the territory was not terra mullius. The decision was mainly supported by two arguments. On one hand, because at the time Spain began the colonisation, the territory "was inhabited by peoples who, although they were nomadic, were socially and politically organized into tribes, under the command of chiefs who were competent to represent them”; and on the other hand, because when Spain colonized the territory, it did so convinced that it was not a territorv with no owner. ${ }^{7}$

(2) About the "legal ties" and the "ies of lerrilorial sovereignty", the Court reached three conclusions: the existence of legal ties of allegiance between the Sultan of Moroceo and certain tribes which inhabited Western Sahara; the non-existence of ties of territorial sovereignty over Western Sahara by Moroceo;

Sahara Occidental', in Sahara Occidenlal. Del Abandono Colonial a la Construcción de un Eslado (Pregunta, Zaragoza, 2019) at $58-90$.

6 For greater knowledge of the technical and strategic-military aspects of the wall, cf. G. \ah Bachir, El Vuro Varroqui en el Sahara Occidenlal. IIisloria, estruclura y efeclos (Élite de Impresión y Publicación, 2017).

7 IVeslern Sahara, Advisory Opinion, I.C.J. Reporls I.97.5, p. 39, par. 8 I.

8 "The material so far examined does not establish an tie of territorial sovereignty between Western Sahara and that State. It does not show that Morocco displaved effective and exclusive State activitv in W estern Sahara. It does however provide indications that a legal tie of allegiance had existed at the relevant period between the Sultan and some, but only some, of the 
and the non-existence of ties which might modify the application of Resolution 15 y (XV) of the General Assembly?

In 2002 the United Xations Legal Advisor, Hans Corell, confirmed some of the observations already made by the Court, stating that,

"The Vadrid Agreement did not transfer sovereignty over the Territory, nor did it confer upon any of the signatories the status of an administering Power, a status which Spain alone could not have unilaterally transferred.

Following the withdrawal of Vauritania from the Territory in 1979 (...), Voroceo has administered the Territory of Western Sahara alone. Norocco, however, is not listed as the administering Power of the Territory in the $\mathrm{U}$ V list of ISG Territories."

It is obvious that, as Moroceo is not the Administering Power, its presence on Saharawi territory can only be described as that of an occupying power.

In the same sense, and even if finally the ECJ Ruling to which I shall refer later disregards the fact, it is worth recalling that, in his conclusions prior to the EC.J Ruling of February 2018, the Advocate General reached the conclusion that Morocco" is the occupying power of Western Sahara" ", after indicating the following:

"it is appropriate to examine whether the Kingdom of Morocco's presence in Western Sahara is an occupation within the meaning of Article $1^{2}$ of the 1907 Ilague Regulations that the Union cannot recognise or to which it cannot render aid or assistance. According to that provision, "territory is considered occupied when it is actually placed under the authority of the hostile army' (...) In that regard, it should first of all be stated that the existence of a state of occupation is a question of fact.(...) Furthermore, the evistence of a Vorocean occupation in Western Sahara is widel recognised, even by Ilans Corell."

Ile went on to note that

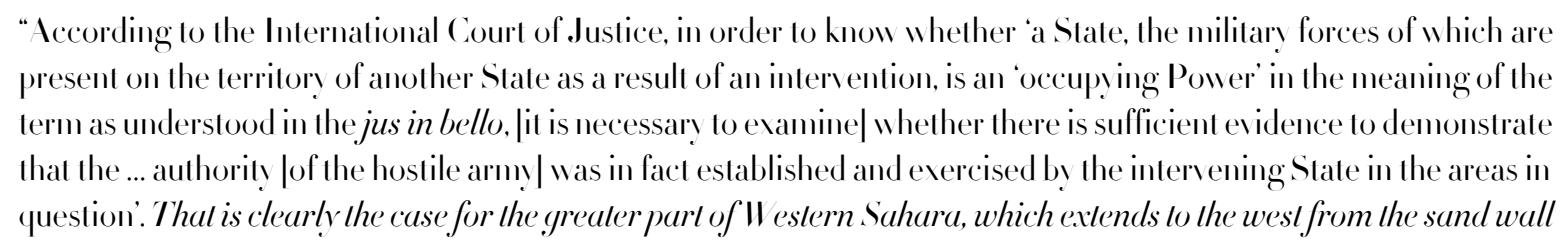

nomadic peoples of the territory" (Ibid., par. 107.)

9 "The materials and information presented to the Court show the evistence, at the time of Spanish colonisation, of legal ties of allegiance between the Sultan of Worocco and some of the Tribes living in the territory of W estern Sahara. They equally show the existence of rights, including some rights relating to the land, which constituted legal ties between the Vauritanian entity, as understood by the Court, and the territory of Western Sahara. IIowever, the Court's conclusion is that the materials and information presented to it do not establish any tie of territorial sovereignty between the territory of Western Sahara and the kingdom of Morocco or the Vauritanian entity. Thus, the Court has not found legal ties of such a nature as might affect the application of Resolution 1514 (XV) in the decolonization of Western Sahara and, in particular, of the principle of selfdetermination through the free and genuine expression of the will of the peoples of the Territory (see paragraphs 5 f 59 above)" (Ibid., par. I62). It should be remembered that, as Professor Carrillo recalled, "except for the colonial enclaves, the international legal status of all non-self-governing territories must be respected just as by the administering powers as by third party States, even in the situation that there had been alleged legal ties between the non-self-governing territory and a third party State before the appearance of the colonial power. (...) The historical entitlements, except for the cases of colonial enclaves, cannot hinder the application of the principle of free self-determination." J. A. Carrillo Salcedo, Libre determinación de los pueblos e integridad territorial de los Estados en el dictamen del T.I.J. sobre el Sáhara Occidental', X XIX-I Revisla Española de Derecho Inlernacional $(1976)$ at 18 .

10 UN Doc.S 2002 161, of 12 February 2002.

" Opinion of Adrocate General Wathelet of 10 January 2018 , Case C-266 ı6, EU: C: 2018:1, par. 258. 
buill and controlled by the Voroccan army and which has been under the aulhority of the Kingdom of Vorocco since ils annexation in two stages (in 1976 and in 1979). It has been administered in a structured manner by the Kingdom of Vorocco since that time, without the consent of the people of I eslern Sahara, which has not yet exercised its right to self-determination."

The Advocate General concludes that moreover,

"It should further be noted that the existence of an occupation is not limited to the continental territory, but also extends to the internal waters and to the territorial sea ${ }^{\text {"12 }}$.

For all these reasons, and in spite of the insistence of the institutions of the European Union and some States, in the wake of the EC.J Rulings of 2016 and 2018 it is no longer possible to claim that Moroceo is the territory's administering power; not even the "de faclo administering power", a perverse expression that began to appear in any thing but innocent fashion for the first time in Kofi Annan’s reports in the late rg9os, and which the EU has used in order to attempt to justify the agreements it has signed with Moroceo. In international law there is no such institution as "de faclo administering power". An administering power is the State recognised by the United Vations as being in possession of the right to administer a colonial territory until its population exercises the right to self-determination. Moroceo has never been granted such a mandate by the U X. Whoever does not exercise the de iure administration of the territory does so in violation of international law. Morocco is the occupving power.

\section{(C) TIIE "IIBER ITED TERRITORIES"}

Following construction of the wall and, as consequence, the POLIS ARIO Front's forced withdrawal to the west thereof, in other words, once the map of occupation as we know it today had been drawn up, the Sahrawi people began to call "liberated territories" those that have since that moment been under their control. Although this term is ypical of times of war, it does not seem quite appropriate, since only some areas of this part of the non-autonomous territory, the international borders of which are not questioned, were occupied by Moroceo, and only briefly, during some moments of the conflict between 1976 and 1979."

In any case, aware of the need to exercise the functions of a State in their territory, and given the impossibility of doing so in the part now occupied by Moroceo, from the very beginning of the war of national liberation, it is in this part of the territory where Sahrawi leaders have issued any declarations and performed any actions of relevance to international relations.

Thus, the first and most important of these, the proclamation of the Sahrawi Democratic Republic (SDR), took place on February 27, 1976 in the Lown of Bir Lehlu. The fact that its President, Mohamed Abdelaziz, underlined this fact upon communication of the proclamation of the new State to the Fourth Commission (November II, 1976 ), is an eloquent reflection of the Sahrawi leaders' determination to

\footnotetext{
12 Ibid., par. 2,8-2 0 \%.

3 Between 1989 and 1991 Tifariti regained its importance because of the commencement of works to build various administrative and health centres. But shortly before the beginning of the ceasefire, the Moroccan army bombed the city, destroying practically every thing that had been constructed.
} 
exercise effective control over their territory, aware of the fact that a Government that proclaims the independence of a territory needs to exercise effective control over the latter.'1

The importance of this question for both parties was highlighted during the XII Congress of the POLIS ARIO Front (December 2007), held, despite the Moroccan Government's protests, in Tifariti, 7o kilometres to the east of the wall, as the decision was taken here to intensify the effectiveness of Sahrawi government over the territories under its control, accelerating the development of this area. The Moroccan Government's reaction was immediate, evidencing the significance within its annexationist aspirations of this part of the territory. In the words of the U I Secretary General, "On 3 March 2oo8, in a meeting with the Force Commander of MINURSO, the Moroccan military threatened action by 'adequate means', including 'air strikes', to prevent further construction in the area of Tifariti”. ${ }^{5}$ Moroceo is perfectly aware that, in spite of the immense power of its allies, and even if political situation in the Maghreb and Sahel today plays in its favour, however long it waits, so long as the POLIS ARIO Front controls this part of Western Sahara, the territory will never be annexed.

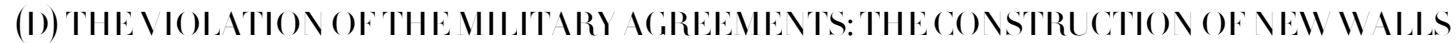

Given that the MINU RSO has neglected its main function, reflected in that "R" which is such a source of irritation for Moroceo and its allies, since it is a reminder that this is a UN mission to organise and guarantee the holding of the referendum in Western Sahara, and it being clearly impossible to monitor the human rights situation in the territory (in my opinion, any U Y mission, by its very nature, has a minimum obligation to inform the Organisation vis-à-vis the human rights situation in the territories in which it acts), the mission members basically limit themselves to "supervising" the ceasefire, reporting any activity that may threaten the latter, and controlling mine clearance operations.

One of the most serious crises to have arisen in the vicinity of the wall in recent times took place between August 2017 and January 2019 in the village of Guerguerat, situated in the south-west of Western Sahara, beyond the territory occupied by Moroceo. Two facts underlined the fragility of this "non-war" situation and the permanent instability of this "border", the very existence of which is a flagrant violation of the principle of uti possidelis iuris, one of the main principles of international law.

One of these is related to the Moroccan plans to asphalt the route that connects the occupied zones of the south of the Western Sahara with Mauritania, in the aforementioned village of Guerguerat. The workers' arrival in the area, accompanied by Moroccan troops,provoked the rapid reaction of the POLISARIO Front, which put its army on standby. Officially, Morocco intended to carry out mine clearance tasks, but the real objective was to improve the state of this path, to turn it into a road and facilitate the transport of goods from the occupied territories. The other crisis was related to the announcement (yet another) that a rally ( Ifrica Eco Race) was going to cross the border at this point, which it eventually did during the first

\footnotetext{
1/4 U Doc. A C.1/31 SR.22, par. 3 I.

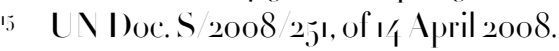


week of 2019. Although there were moments of maximum tension, when only a few hundred metres separated the Sahrawi and the Morocean troops, the situation soon calmed down. These are very infrequent situations, but they reflect an underlying tension. ${ }^{16}$

In any case, it is no coincidence that these events occurred shortly after publication of the General Court of the European Union ruling with regard to the legality of the free trade agreements signed between the EU and Morocco. Among others, the Court's assertion that the Western Sahara is not part of Moroceo (nothing new; the IC.J had already stated this in 1975, but now it is the turn of the highest European court to do so) put on the front pages of the world's leading newspapers a conflict that had begun in the middle of the Cold War, and recalled the fact that well into the $2{ }^{\text {st }}$ century, the largest nonautonomous territory in Africah as still to be decolonised.

One of the major violations of the military agreements, specifically military agreement $n^{o}$, which has been condemned on several occasions by the U I Secretary General, is the construction by Moroceo of two more sand walls! One in Mahbas, near the Agerian border town of Tinduf, and the other in Auserd, in the south-west of the territory, 80 and $3^{\circ}$ kilometres long respectively. Moroceo has ignored the MINURSO's instructions to dismantle both walls, arguing that they are necessary in order to deal with flooding, wind and smugglers. ${ }^{17}$ This is one of the most serious violations of the peace agreements, since it represents a further attempt to consolidate the annexation of that part of the Sahrawi territory, in violation of the aforementioned principle of uti possidetis iuris. As we know, in virtue of this principle, or the intangibility of the frontiers established in the colonial era, border delimitations must be respected and maintained as they had been inherited from the former metropolis (frontiers drawn up in international agreements made by the former colonisingowners and those deriving from the simple internal administrative divisions of the colonial powers). This principle, whose objective, in the words of the IC.J was "lo preserve the conquests of the peoples who have struggled for their independence, and to avoid the breakup of a balance which would lead to the African continent losing the benefit of so many sacrifices (...) in order to survive, develop and progressively consolidate their independence", constitutes "a principle of general order necessarily linked to decolonisation wherever this might occur" ${ }^{18}$. In fact, it can be stated that the principle of territorial integrity is for States what the uli possidetis iuris principle is for peoples subjected to colonial or foreign domination.

As was to be expected, and despite António Guterres's repeated condemnations in his reports of the seriousness of these violations ${ }^{\prime \prime}$, Security Council resolutions regarding the Sahrawi conflict do not even

16 Cf. J.D. Torrejón Dominguez, 'The Crisis at Guerguerat and the Escalation of the WVestern Sahara Conflict', SYbIL (2018) at $115-126$, |doi: 10.17103 Sybil.22-21|.

17 U D Doc.S 2019282 , of i April 2019 .

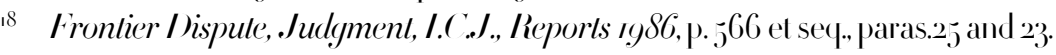

19 U D Doc. S 2018 889, of 3 October, and S 2019282 , of a April 2019 . The Secretary General also condemned in the first of the reports mentioned that the construction of various buildings by the POLIS ARIO Front constitutes a violation of military agreement number I. It should be remembered that this agreement, which has never been officially published (available here), was signed in 1997, and that it covered "the period from now until the start of the transitional period (I)-I)ay, the day the provisional list of Sahrawi people eligible to vote is published) within the framework of the present peace process". The census was made public in 2000. It is logical that, in the absence of other agreements, the Secretary General and the MIVU RSO refer 
mention the question...

\section{(E) TIIELINDVIINE ISSSE}

Within the MINURSO's few remaining functions, apart from monitoring and reporting the continual violations of the Peace Plan, probably the most important is that of clearing the area of landmines. Since construction of the $\mathbf{W}$ all began in the 1980 s, the lands on both sides of it have been riddled with mines. Even in these "non-war" times this is a crucially important question, since every year accidental explosions cause ether death of dozens of Sahrawis as, insofar as circumstances permit, they continue to practise their nomadic life. As the U N M AS (Uniled Nations Mine Aclion Service), acting since 2008 as a component of the MINURSO, has indicated in this respect "these explosive hazards continue to endanger the lives of local nomads, daily activities in settlements, as well as the livestock on which they are dependent, United Vations military observers monitoring the ceasefire and humanitarian workers”.20.

The MINC RSO itself has acknowledged that "owing in part to the vast expanse of W estern Sahara, it has not been possible to obtain a comprehensive picture of the number of accidents related to mines and explosive remnants of war in the Territory", since 1975 over 2,500 people have died or been mutilated as a result of explosions ${ }^{21}$.The MINU RSO continues to supervise mine clearance on both sides of the wall, but added to the weather conditions (the Siroceo, sand movements and the rain have moved and buried many mines, on occasions making exact localization impossible), is the absence of Moroccan cooperation. For this reason, the MINU RSO is obliged to include in its reports the data provided by Moroce, the accuracy of which is impossible to confirm, while directly supervising the mine clearance operations undertaken by the POLIS ARIO Front.

\section{(F) TIIE W ILL IND "ILLEG NL IVIIIGR ITION"}

Although its author is not deserving of a single line in this work, one should at least mention, as a curiosity,

to the latter; but, in my opinion, it has not been in force for almost twenty vears. It is obvious that the construction of new sections of the wall attack the heart of the Peace Plan, as it seeks to consolidate a foreign military occupation, as occurs with the construction of the Israeli wall in the occupied Palestinian territories. But it is ridiculous to claim that the POLIS ARIO Front violates the Peace Plan in attempting a minimum development of the part of its territory that remains under its own control and expect it to respect military agreements negotiated with a view to the holding of a referendum on self-determination, when Morocco has ruled out such a referendum, the main objective of the entire Peace Plan.

20 It's activity on Sahrawi territory has materialized in the following measures: 1/7, 513,196 square meters of hazardous areas released and or cleared; 35 of 6 1 known minefields and 425 of 498 known cluster strike areas cleared; 9,278 km of routes verified or cleared for U I military observers' patrols (I,18 I km verified since I.July 2015); 7,866 landmines removed and destroved; 8,372 explosive remnants of war (ERII) destroved; 23,6/3 sub-munitions destroved; 3,228 MINURSO personnel received ERII Awareness Briefings; 73,0/4 local and nomadic people received risk education (RE); $27^{2}$ individuals (28 survivors of mine accidents and 22, of their dependents) received victim assistance. Over t,ooo mine victims have been recorded east of the berm

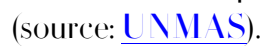

${ }_{21}$ "Since 1975 , Moroccan authorities have registered at least 2,17ı accidents caused by mines and explosive remnants of war." (U I Doc.S $2008 / 25$, of 1/4 April 2008).

${ }^{22}$ I use the expression "illegal immigration" in purely expository fashion, although I consider that the action of human beings 
the recent proposal by the US President, Donald Trump, to the Spanish and European Union Foreign Minister, Josep Borrell. The former has suggested to the European Union that, following the model being employed on the Mexican border, it should build a wall in the Western Sahara (another one?) to stem the arrival of immigrants ${ }^{23}$. But leaving aside this perverse proposal, the fact is that, as has been reported by such important NGOs as SOS Racismo, Médicos del Mundo and Doclors Wilhoul Fronliers, since the identification process was paralysed in 2000, the Morocean authorities have been using the issue of immigration and the wall for propaganda purposes.

These organisations and the POLIS ARIO Front itself have on numerous occasions condemned the abandonment by the Morocean police of sub-Saharan immigrants near the wall. These people, arrested by the police in other areas of Morocco, sometimes as far away as the border with Ceuta or Melilla, have reported that, after being detained, they have been transported in military trucks to zones near the wall, where they have been abandoned to their fate. ${ }^{21}$

\section{(G) TIIELEGILST ITU SOF TIIE TERRITORIES CONTROLLED BY TIIE POLIS IRIO FRONT}

The aforementioned decision taken at the 2007Congress of the POLIS DRIO Front had a clear purpose: show the world that, though much of its territory is subjected to military occupation, the IV estern Sahara, the S1IDR, exists. The construction of buildings (hospitals, administrative centres, and even a fledgling university) in Tifariti and the steady stream of refugees arriving from the Tinduf camps is a means of reaffirming and consolidating Sahrawi control of their own land (or at least this part of it)and is also a way of asserting that the S IDR is a State, as it satisfies the conditions established by international law: a population, a territory and a government capable of exercising its authority over the territory in effective fashion. Yet it is unable to do so in the whole of the territory, but in a significant part thereof, yes.

As I mentioned earlier, the EC.J stated very clearly that W estern Sahara is not part of Morocco. Given that the European court's jurisprudence vis-à-vis the legality of the free trade and fishing agreements between the European Union and Moroceo has already been the subject of various doctrinal works ${ }^{25}$, I

who flee war, horror or hunger, and risk their lives to find a better life in Europe, cannot be described as illegal.

23 See the reference here.

¿4 "Last week, the Morocean security forces abandoned hundreds of irregular sub-Saharan immigrants to their fate at different points of the south-eastern Moroccan border (...) The Moroccan security forces have located and housed in military camps in the vicinity of the defensive wall dozens of immigrants who had previously been abandoned in the desert by members of the same security forces" (La I anguardia, ig October 200弓). In the same sense, cf. El Confidencial, i6 October 200 ; El Wundo, 13 October $200 z$ El País, 11 October 2005.

25 Apart from my work 'La jurisprudencia del TJUE En relación con la legalidad de la explotación de los recursos naturales del Sahara Occidental o el dogma de la inmaculada legalidad de la acción exterior de la U nión Europea y sus consecuencias', $^{6}$ RGI)E (2018) at 6ı-11, , cf. A. Annoni, 'C’è un giudice per il Sahara occidentale?', 99-3 Rivisla di Dirillo Inlernazionale (2016) at 866-876 |http: hdl.handle.net/11392 2352826|; F. Dubuisson and G. Poissonnier, 'La question du Sahara occidental devant le Tribunal de l’U nion européen, une application approximative du droit international relatif aux territoires non autonomes', 2 Journal du Droil Inlernalional (2016) al 503-522 |urn:issn:002ı-8170|; J. Ferrer Lloret, 'El conflicto del Sahara Occidental ante los tribunales de la U nión Europea', 彳2 RGI)E (2017) at 15-6/; J. González Vega, "La Guerra de los Mundos: realidad versus formalismo jurílico o el poder de la interpretación (a propósito de la sentencia T.JU E de 27 de febrero de 2018 , W estern Sahara

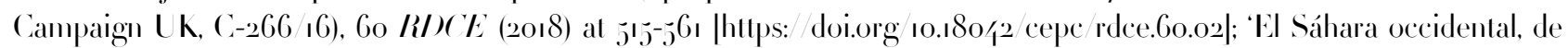


shall only offer a cursory analysis thereof, in order to focus on a question of critical importance, which arises precisely from this affirmation which, however obvious, is far from irrelevant.

Is is indicated by this jurisprudence, for the agreements not to infringe international law, the consent of the Sahrawi people is necessary. I shall not dwell on the sense of shame produced by the Council and the Commission's interpretation, recently endorsed by the European Parliament, ${ }^{26}$ according to which the approval of the trades union, administrative and political associations of the (non-autochthonous) inhabitants of the territory equates to this consent. The United Vations recognises the right to selfdetermination of the people of the Western Sahara; not of the "local populations", and even less so in the case of the colonists brought by Moroce to the territory in violation of the Geneva Conventions of ig/9, which specifically prohibits the transfer of the population of the occupying State to the occupied territory. If I broach this question it is because the European institutions have sought to ignore the will of the native population of the territory. If, on the one hand, the POLIS ARIO Front, "the only legitimate representative of the Sahrawi people”, refused to consent to any agreement that involved the exploitation of the natural resources of its territory in which Moroceo participated, on the other, there was no consultation of the Sahrawi population in the occupied territories, neither of those Sahrawïs the Tinduf refugee camps... nor of those living in the part of the territory under Sahrawi control.

But the General Court made a subtle reference to an important question. In its 2015 ruling, which annulled the decision regarding the liberalisation agreement in its application to the territory of the Western Sahara, confirmed an evidence that was even acknowledged by the European institutions themselves, albeit one which later both the Council and the Commission and the EC.J attempted to ignore: the agreement is applied in Western Sahara, "or more specifically, in most of this terrilory, controlled by the King of Moroceo" ${ }^{27}$. This jurisprudence states without further detail that if the requirement of the consent off the Sahrawi people were fulfilled, the agreements would be applicable in II eslern Sahara. Does this mean that the agreements between the European Union and Moroceo are applicable throughout the territory? ¿Would they, therefore, be applicable in the part of the territory under Sahrawi

nuevo, en Luxemburgo: las implicaciones de una unión de Derecho', j6 La Ley U nión Europea (February 2018); P. Ilipold, 'Self-determination at the EuropeanCourts: The Front POLIS IRIO Case or The Unintended Awakening of a Giant', 2-3

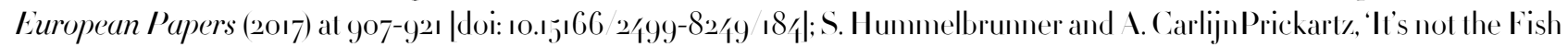
that Stinks! EU Trade Relations with Morocco under the Scrutiny of the General Court of the European U nion', $3^{2}\left(8_{3}\right)$ U trecht Journal of International and European Law (2016) at 19-10|http:/ doi.org 10.5334 ujiel.322|; E. Milano, Front POLIS \RIO and the Exploitation of Vatural Resources by the Administrative Power', 2-3 European Papers (2017) at 953-966 |doi: 10.15166 2/99-82/9 182|; Odermatt, J., 'Council of the European Union v. Front Populaire pour la Libération de la Saguia-El-

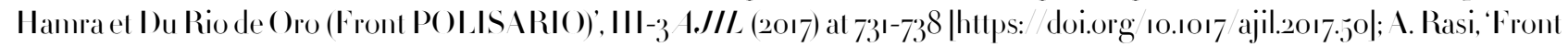
POLIS ARIO: A Step Forward in Judicial Review of International Igreements by the Court of Justice?', 2-3 European Papers

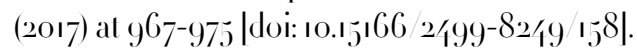

26. EP Resolution of a January 2019 (not yet published in the Official Journal). Evidencing its clear intention to ignore international law, the Parliament previously rejected an opinion from the Court of.Justice on the compalibility with the Treaties of the proposed Sustainable Fisheries Parinership Agreement belween the European I nion and the Kingdom of Morocco, the Implementalion Prolocol therelo and an exchange of lellers accompanying the said Igreement (EP Motion for a Resolution of 6 February of $2019,201925(6 \overline{5}$ (RSP)).

${ }_{27}$ The high courts has recognised that the agreements are applied "de faclo", as if this expression did not imply that their non-application "de iure" is purely and simply contrary to international law. 
control? Can the European Union negotiate with Moroceo with regard to the part of the territory that is free of military occupation? Accepting the European institutions' perverse interpretation of what should be understood as "consent of the people of Western Sahara", does the European Union require the consent of these "local populations", in this case genuinely autochthonous? Should it be understood that the agreements are also applicable to the products of unoccupied Sahara?

And these questions give rise to others that are equally important: what is the legal status of the territory under Sahrawi control? Terra nullius in the zsst century? What legal status do the European institutions attribute to the POLIS IRIO Front? Is it a national liberation movement ... or a terrorist movement controlling a territory by force, in similar fashion to what occurs in the "Islamic State"? Are we faced with a legal loophole in international law?

Will the U Y and the EU permit the consolidation of the legal annexation of an important part of the territory, allowing the other part to remain in a kind of legal limbo, particularly in such an unstable part of the world, preventing moreover progress towards the desirable future of a strong, united Maghreb that would provide greater stability?

\section{(II) SOMECO\CLUSIO\S}

International law has appropriate responses to all these questions. In fact, the International Court of Justice itself provided them in the case of the construction of the Israeli wall in the occupied Palestinian territories. The Advocate-General, Melchior Whatelet, echoed them in an excellent report ${ }^{28}$ which, unfortunately, the EC.J magistrates, bowing to the pressure exercised by the institutions of the European Union and some States, did not even mention, in a ruling that, like the aforementioned European Parliament resolution, is an embarrassment, since the Court ignores the Law and exercises a political function that does not correspond to it. ${ }^{29}$

As the EC.J states, Western Sahara is not part of Morocco and is a non-autonomous territory pending decolonisation. Even if successive governments have insisted on claiming the contrary, Spain continues to be the administering power of the territory. Consequently, and as the Advocate General declares, Moroceo is the occupving power in the territory, so the applicable law in the occupied territories is humanitarian international law. The construction and maintenance of the wall constitutes a violation of the principle of uti possidetis iuris. Although the institutions of the European Union (Council, Commission and Parliament) deny the fact, "the negotiation and conclusion with the Kingdom of Moroceo of an international agreement applicable to Western Sahara and to the waters adjacent thereto constitutes in itself de iure recognition of the integration”. For this reason, the European Union incurs international responsibility for violating the obligation not to recognise an illegal situation resulting from a breach of the right of the people of Western Sahara to self-determination and not to render aid or assistance in

28 Opinion of to January 2018 , IV eslern Sahara Campaign U K, The Queenv. Commissioners for Iler Iajesty's Revenue and Cusloms, Secrelary of Slale for Environment, Food and Rural 4/fairs, C-266/ I6, EU:C:2018:1.

${ }_{29}$ Judgment of 27 February 2018, I eslern Sahara Campaign UK, The Queen v. Commissioners for IIer Majesly's Revenue and Cusloms, Secrelary of Slale for Environmenl, Food and Rural 1/fairs, 266/16, EU:C:2018:118. 
maintaining that situation.

The S IDR is a State partially recognised by the international community, but is a founder member of the African Union and controls part of its territory, in which it effectively exereises state functions. It is true that many factors combine in this conflict in opposition to the application of international law and to the Sahrawi State being able to exercise its powers throughout the territory, at least in the short or medium term: the scant or zero interest of the major powers and their allies in finding a solution to this conflict; the peaceful nature of the Sahrawi people's struggle for their self-determination; the current international context and the Sahrawi territory's proximity to the Sahel; the bullying of the Morocean Majzen, that continually threatens Europe with opening the gate to immigration (it opens them periodically when it wishes to exert pressure), which provokes incidents alongside the fenced borders of Ceuta and Melilla or threatens not to cooperate with the European Union in the question of Islamic terrorism; the supposed danger of instability in Moroceo in the event of the latter "losing" territories that do not belong to it; the unconditional support for the illegal annexation of the territory expressed by a permanent member of the Security Council... All these factors make it very difficult to reach a solution to the conflict in accordance with international law. However, and although the day of Morocco's withdrawal from Western Sahara seems distant, it is equally difficult to imagine the SADR ceasing to control and administer the part of the territory under its control, which appears to render this conflict eternal.

In the occupied territories the gulf that exists between the Sahrawi population and the settlers has continued to widen since the Moroccan Government has used the latter to attack the autochthonous population following the events of Gdeim Izik. The Sahrawi population continues to be marginalised in their own territory, subjected to systematic violations of their human rights. In the refugee camps the situation is gradually deteriorating, as has been noted on various occasions by the U I Secretary General. Humanitarian aid, indispensable for the mere survival of the population in the inhospitable lands of southern Algeria, is decreasing daily, which means that the social situation of much of the refugee population is gradually becoming unsustainable. There is no doubt that the maintenance of the slatu quo of the territory is neither an option nor a solution, and that only with justice will there be peace. The United Vations is obliged to promote the decolonisation of the territory. In the first place, for the sake of its own interest and credibility. But most particularly, because this is the U V's debt to a people that laid down its weapons in the belief that that the Organisation would impose a solution in accordance with international law.

In spite of the dark picture painted by the conflict and the EC.J's outrageous recent jurisprudence, in the five years since the POLIS IRIO Front decided to appeal to the courtsto demand compliance with international law, the Sahrawi people has made more progress towards self-determination than in the previous forty years of occupation. As a jurist, I continue to trust that, as has occurred throughout history in other spheres of human rights, the courts will gradually see reason, and the Law will achieve something that polities is far from achieving: the application of international legality and the Sahrawi people's recovery of control over all of their territory. 